\title{
Supporting the Availability of the Basic Needs of Lidah Wetan Society Affected by Covid 19
}

\author{
Ajeng D. Kartika ${ }^{1, *}$, Yunanfathur Rahman ${ }^{1}$, Dwi I. Julaikah ${ }^{1}$ \\ ${ }^{1}$ Department of German Language, Universitas Negeri Surabaya, Indonesia \\ ${ }^{*}$ Corresponding author. Email: ajengkartika@unesa.ac.id
}

\begin{abstract}
The outbreak of the Covid 19 virus or what is commonly referred to by the community as the Corona virus has been declared a pandemic in Indonesia. The spread of the virus is so fast, especially in big cities, including Surabaya, with the highest number of victims infected with Covid 19 in East Java. This has caused public unrest in Surabaya because the Covid 19 pandemic has an impact on all aspects of life, not only on the health aspect but also on the economic aspects of the community. The economic impact is felt most by the middle to lower class people, especially those who have not been able to work as they should have since the existence of the PSBB (Large-Scale Social Restrictions) in Surabaya. Fulfilling basic daily needs is difficult for the middle to lower class affected by Covid 19. Because of this, some parties have empathy to help people meet their needs during this pandemic. One of Unesa's closest neighborhoods that is economically affected is the Kelurahan Lidah Wetan. Most of the people of Lidah Wetan depend on Unesa for their lives. They are entrepreneurs selling food, opening photocopying and printing services, and selling daily necessities of which $90 \%$ of the consumers are students and the Unesa Lidah Wetan academic community. After the implementation of WFH (Work From Home) and students studying online from the automatic home of the Lidah Wetan community around Unesa, their income decreased significantly. For them, this will affect the stability of food security because it increases their burden in meeting basic needs, such as rice, sugar, cooking oil and other basic needs. Through this PKM, the people of Lidah Wetan who are affected by Covid 19 will be given basic food assistance that can be used to meet their daily needs.
\end{abstract}

Keywords: COVID-19 pandemic, basic needs, food stability

\section{INTRODUCTION}

It cannot be denied that the stability of the Indonesian state from various sectors has experienced shocks due to the Covid 19 pandemic that has occurred since February. Covid 19 or also known as the Corona virus, which since the end of 2019 began to spread in the city of Wuhan, China, has now spread in Indonesia. The spread that was so fast and the expanding area affected by Covid 19 made the World Health Organization (WHO) increase the status of world health which was previously endemic to pandemic, which means that Covid 19 has become a global outbreak.

Even though the death rate caused by the Covid 19 virus cannot be said to be high, the rapid spread rate in the past 2 months in Indonesia has raised its own concerns for the community and government. The government then took a policy to limit physical contact by temporarily limiting activities in education, offices, industry, transportation and other sectors. The most felt impact of this policy is the slowdown in the national economic sector in various sectors which has a direct impact on society, especially those at the lower level.
It can be observed together at this time through news reports in both print and online newspapers as well as television broadcasts that there have been job cuts at companies in Indonesia. Statqo Analytics reports that there is public concern about the stability of food security given the difficulty of meeting basic daily needs for certain groups of people. Currently, many Indonesians claim that they are no longer able to meet their basic needs without loans.

Food security during the Covid-19 pandemic is an issue that is always being discussed, including in Indonesia. One of the main problems is how much the government's ability to handle the food problem. Meanwhile, it is not certain when the Covid19 outbreak will end. This was revealed by an economist from the University of Indonesia (UI) Firmanzah. He said the people's purchasing power has increasingly decreased seeing the wave of layoffs (PHK), because many companies went out of business due to lack of income when hit by the corona virus outbreak. Of course, this condition greatly affects food security.

Public concern about food stability also occurs in Surabaya as a city with a high number of Covid 19 spreads in Indonesia. Lidah Wetan as one of the sub-districts in Surabaya is also planning a significant impact considering that many people 
depend on mobility on the Unesa Campus. Community income has decreased drastically, there are even groups of people who have no income at all because they no longer have a job. Facing a situation like this requires responsive and appropriate action to support the food stability of the Lidah Wetan community through the distribution of regular basic necessities.

The Covid 19 pandemic is a global problem and of course a common problem for the Indonesian people. The slowdown in economic growth as the real impact of this pandemic is inevitable. The disruption of economic stability in large cities is very pronounced, including in Surabaya as the second major city in Indonesia. Not only native Surabaya residents but also immigrants from outside Surabaya depend on their livelihoods in Surabaya.

Lidah Wetan is one of the areas affected by Covid 19. The people's economy cannot run as usual. The location of the area near the State University of Surabaya (Unesa) ultimately makes most of the community entrepreneurial in the field of providing services to students, for example opening food stalls, photocopy and printing services, laundry services, and grocery stores. The main consumers of these services are students and the Unesa academic community. However, since the outbreak of the Covid 19 virus in March, Unesa has established a WFH (Working From Home) policy for lecturers and employees and online lectures for students. Automatically, since the implementation of this policy, the community service sector of Lidah Wetan has decreased turnover, some have even had to close due to lack of consumers and the cost of maintaining equipment is not cheap.

\subsection{Target and Solution}

Covid-19 transmission occurs through respiratory droplets and direct contact with sufferers. Therefore it is in accordance with government directives that have also been studied by health experts that to prevent the spread of this virus people must carry out work activities at home, maintain physical distance from each other, and implement healthy habits of washing hands and wearing masks (Wang, Ma, Zheng, Wu, \& Zhang, 2020). However, this step certainly has a significant impact on the community's economy because not all jobs can be carried out using the work at home system. Burhanuddin \& Abdi (2020) stated that economic growth in Indonesia as a whole is expected to weaken by $5 \%$ due to the Covid 19 pandemic. This impact is of course also felt in Surabaya as a big city which is the axis of the economy in East Java.

A systematic and structured solution has been implemented by the government in the form of PSBB in Surabaya. However, there are still many residents who violate and leave their homes for various purposes. The government of East Java has also provided basic food assistance. However, in practice in the field there are still residents who feel that this assistance has not been touched. To assist the performance of the government in providing basic food assistance to the community, care and participation from agencies located in areas affected by Covid 19 is needed.

\section{METHOD}

The process of implementing the PKM program entitled Realizing Food Security Stability for the Covid-19 Affected Tongue Community consists of several stages as illustrated follows :

\subsection{Field Observation}

In the early stages, field observations were made of Lidah Wetan residents to classify residents affected by Covid 19 who were in the pre-prosperous or lower middle class. The observation was continued with an analysis of the appropriate basic needs for the residents.

\subsection{Activity Planning}

In the planning stage, a systematic planning is carried out in the form of a PKM proposal. This proposal contains the frequency of program implementation, details and scheduling of the implementation of activities, the division of team tasks, and also the required funding.

\subsection{Implementation}

The next stage is the implementation which begins with the process of shopping for goods then packaging and continues with the distribution of basic foodstuffs to the Lidah Wetan community according to a set schedule.

\subsection{Evaluation}

After completing the entire implementation of the activity an evaluation is held. At this stage, an evaluation of the planning process to the distribution process is carried out. The shortcomings that occur can be used as material for analysis and improvement for further program activities. In this stage, a final activity report is also prepared which is an activity accountability report.

As a form of responsive action to the problems of the community that are affected by Covid 19 in this community service program, the assistancing method was applied. Assistance is realized through the distribution of regular basic foodstuffs to support the stability of the community's food so that the community's resilience can be maintained.

This activity requires community participation. The first participation is in the form of collecting data on people who most need basic commodities. The community determines the priority scale for 200 families in need. The second participation is participation during distribution to recipients. The distribution process is carried out by community groups based on data. 


\section{RESUlt AND DISCUSSION}

Lidah Wetan is one of the sub-districts in West Surabaya and is located in direct contact with Surabaya State University. The people of Lidah Wetan who are affected by Covid 19 are generally those who work as food sellers and service providers such as laundry and food vendors. They no longer receive daily income like before. So they have difficulty meeting their daily needs and it is difficult to meet food needs for themselves and their families. They no longer receive daily income like before. So they have difficulty meeting their daily needs and it is difficult to meet food needs for themselves and their families. For location determination, previously Unesa conducted a small survey and data collection of affected residents assisted by local RW management, so that the data about residents affected by Covid-19 was quite valid. The counseling and distribution of basic necessities carried out are not the first time, Unesa has carried out since the beginning of the Covid-19 pandemic until now, with a focus on residents around the Unesa Surabaya campus.

The results of preliminary observations showed that there were 200 residents affected by Covid 19 in the Tongue District district. Of these 200 residents, 18 people are not residents of Surabaya. The distribution of groceries is carried out on a scheduled basis every week for 2 months. People who are included in the basic food recipients are those who are financially directly affected by Covid 19 in the sense that they do not have a regular daily income.

The distribution of basic necessities as a whole went smoothly, but that does not mean there were no obstacles. The constraints faced are the recipients of basic food aid who often come outside of the distribution schedule. In addition, some of the names that were already on the list turned out to be not indigenous people who had Lidah Wetan ID cards and this led to repeated scheduling which affected the number of packages that had been prepared. Another obstacle that occurs is that there are different family members who take more than one basic food aid package, thus requiring an increase in the number of basic food aid packages.

The distribution was carried out with due observance of the health protocol as recommended by the government health team. Residents who come must wear masks and bring coupons that have been distributed by the head of the local RT the day before the implementation. They were asked to stand on both sides of the road in a zigzag manner with a distance of at least 1 meter between residents. The PKM Team then accompanied on the right and left sides of the food packages transporting tools that walked between the lines of the community while distributing food packages. In this activity, of course, there was no handshake and the PKM team only put the food packages under the place where the residents were standing. To convey feelings of gratitude and joy, both parties convey greetings with both hands in front of the chest and chin.

The response of village officials and the society was very grateful and felt helped by the assistance from PKM Unesa. It is hoped that Unesa's caring community will help them to meet their daily needs and maintain the stability of their food security. In this case, this basic food assistance is expected to be right on target so that it can benefit people in need so that this activity is also an effort to support a better Unesa's spirit.

\section{CONCLUSION}

The Covid 19 has an impact on all aspects of life, not only on the health aspect but also on the economic aspects of the community, especially Surabaya, the epicenter of the pandemic in East Java. Accordingly, providing food assistance for those affected is one of possible ways to reduce the economic impact of the pandemic. People around the campus were selected to be the recipients of the basic food assistance. The recipients and the village officials appreciated the program held by Unesa as the social responsibility program.

\section{REFERENCES}

[1] Burhanuddin, C. I. \& Abdi, M. N. (2020). Ancaman Krisis Ekonomi Global dari Dampak Penyebaran Virus Corona (Covid-19). AkMen, 17(1), 711-719.

[2] Gugus Tugas Percepatan Penanganan Covid-19. (2020) Data Sebaran Virus Corona. Retrieved from Gugus Tugas Percepatan Penanganan Covid-19 website: https://webcache.googleusercontent.com/search?q=cache: 9backaqsWT4J:htt ps://www.covid19.go.id/

[3] Lai, C. C., Shih, T. P., Ko, W. C., Tang, H. J., \& Hsueh, P. R. (2020). Severe acute respiratory syndrome coronavirus 2 (SARS-CoV-2) and coronavirus disease-2019 (COVID19): The epidemic and the challenges. International Journal of Antimicrobial Agents, 55(3), 105924. https://doi.org/10.1016/j.ijantimicag.2020.105924

[4] Wang, Z., Ma, W., Zheng, X., Wu, G., \& Zhang, R. (2020). Household Transmission of SARS-CoV-2. Journal of Infection. https://doi.org/10.1016/j.jinf.2020.03.040

[5] WHO. (2020). Coronavirus. Retrieved from World Health Organizatiom website: https://www.who.int/healthtopics/coronavirus\#tab=tab_1 